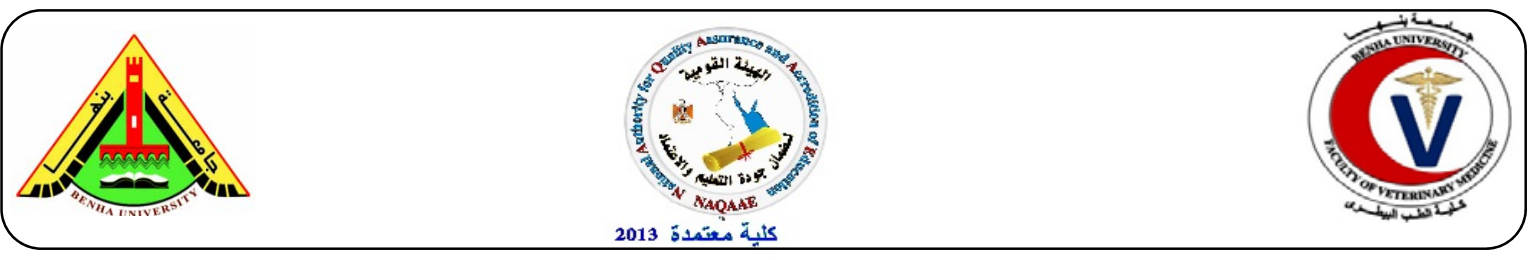

\title{
Evaluation of protective and therapeutic role of zinc oxide nanoparticles and aloin on dextran sulfate-induced ulcerative colitis in rats
}

\author{
Omayma A.R. AbouZaid ${ }^{1}$; Sawsan. M. El-sonbaty ${ }^{2}$ and Heba M. El-sogheer ${ }^{1}$ \\ ${ }^{1}$ Biochemistry Department, Faculty of Vet. Med., Benha University, Egypt. ${ }^{2}$ Radiation Microbiology \\ Dept., National Center for Radiation Research and Technology (NCRRT)
}

\begin{abstract}
A B S T R A C T
This study designed to investigate the anti -inflammatory effect of zinc oxide nanoparticles (ZnONPs) and $\backslash$ or aloe component (aloin) on inflammatory mediators and oxidative stress in dextran sulfate sodium salt induced ulcerative colitis(UC) in rats. sixty-four albino rats divided into eight equal of eight rats each. Group 1:(normal control) received no drugs, group 2:( ulcerative colitis) rats received dextran sulfate sodium salt 3\% in drinking water, group 3:( ZnONPs) rats administered ZnONPs $(5 \mathrm{mg} / \mathrm{kg}$ body weight) orally for 3 weeks, group 4: (aloin ) rats administered orally with $1 \mathrm{ml}$ of aloin $0.1 \%$ daily for 3 weeks, group 5: (aloin $+\mathrm{ZnONPs})$ rats orally administered with $\mathrm{NZnO}(5 \mathrm{mg} / \mathrm{kg}$ body weight) and (aloin $0.1 \%$ ), daily for 3 weeks, group 6: $(\mathrm{ZnONPs}+\mathrm{UC})$ rats with ulcerative colitis orally treated with $\mathrm{ZnONPs}(5 \mathrm{mg} / \mathrm{kg}$ body weight) daily for 3 weeks, group7: (aloin+UC) rats with ulcerative colitis orally treated with (aloin $0.1 \%$ ), daily for 3 weeks, group 8: (aloin+ ZnONPs $+\mathrm{UC}$ ) rats with ulcerative colitis orally treated daily with $\mathrm{ZnONPs}(5 \mathrm{mg} / \mathrm{kg}$ body weight)+aloin ( $1 \mathrm{ml}$ aloin $0.1 \%)$ for 3 weeks. The obtained results revealed that, administration of ZnONPs andlor aloin to rats with ulcerative colitis significantly reduced elevated serum total cholesterol and TG concentrations, and markedly increased the reduced HDL-C level. On the other hand, elevated level of COX-2, IL-6, MDA and TNF- $\alpha$ in UC rats were significantly reduced, with significant increase of the reduced level of GSH. Results suggest that ZnONPs modulates UC, while aloin showed high efficacy to normalize UC tissues and may considered as potential treatment for UC and other inflammatory bowel disease.
\end{abstract}

Key words: zinc oxide nanoparticles, aloin, ulcerative colitis, inflammatory mediators

(http://www.bvmj.bu.edu.eg) $\quad$ (BVMJ-30(1): 208-218, 2016)

\section{INTRODUCTION}

$\mathrm{C}$ hronic inflammation is involved in pathogenesis of many chronic diseases, including inflammatory bowel disease. Therefore, the suppressing the production of pro-inflammatory molecules could be an important target for the prevention or treatment of various diseases (Park et al., 2009). Ulcerative colitis is an inflammatory bowel disease (IBD) that causes long lasting inflammation and ulcers(sores) in the digestive tract. Ulcerative colitis affects the most inner lining of large intestine (colon) and rectum (Rakel, et al., 2014). In fact, the exact cause of ulcerative colitis is unknown. Researches believe that factors such as over active intestinal immune system, genes, and environment may play role in causing ulcerative colitis, (Dignass, et al., 2012). Induced intestinal inflammation are one of the most commonly used models because they are simple to induce, the onset, duration, and severity of inflammation are immediate and controllable. Dextran sulfate sodium salt (DSS) induced colitis are wellestablished animal models of mucosal inflammation that have been used for over 2 decades in the study of IBD pathogenesis and preclinical studies. The DSS-induced colitis model has some advantages when compared to other animal models of colitis. For example, an acute, chronic, or relapsing 
model can be produced easily by changing the concentration of administration of DSS. Moreover, dysplasia that resembles the clinical course of human UC occurs frequently in the chronic phase of DSSinduced colitis (Neurath, et.al., 2000; Wirtz, et.al.,2007; Wirtz et al., 2007). Zinc oxide $(\mathrm{ZnO})$ has optical, magnetic, antibacterial and semiconducting properties. Its nanostructures exhibit interesting properties: high catalytic efficiency and strong adsorption capacity. This is extensively used in many applications such as cosmetics (Chabni et al., 2011; Ramimoghadam, et al., 2012). The electrostatic properties of zinc oxide determine that it can have different charges on its surface under acid and base conditions. This can be used in the conjugation of therapeutic agents and also to internalize NPs within cancer cells, as they are high in phospholipids with negative charges on their surface (pilar, et al., 2015). The $\mathrm{ZnO}$ NPs behave as genotoxic drugs, since they induce micronucleus formation in cells. These results could be helpful in designing more potent anticancer or anti-inflammatory agents for therapeutic uses (Wahab et al., 2013). Reduced zinc may exacerbate the oxidative stress mediated complications and proved that $\mathrm{ZnONPs}$ have the ability to modulates MDA (Umrani and Paknikar, 2014). Aloe vera is known for their nutraceutical and cosmeceutical properties including anti-viral, anti-bacterial, laxative, antioxidant, anti-inflammatory, anti-cancer, anti-diabetic, anti-allergic, immunostimulant, UV protecting activity and so on (Choi and Chung, 2003; RodriguezGonzalez et al., 2011; Rayet al., 2012, $2013 \mathrm{a}, \mathrm{b})$. The triterpenoid lupeol and the steroids cholesterol, campestrol and bsitosterol were all found in whole leaf extracts of aloe vera (Waller et al., 1978; Ando and Yamaguchi,1990) Lupeol, campestrol and b-sitosterol were found to be significantly anti-inflammatory in wounded mice (Davis et al.,1994b). Aloin is known to be hydrolyzed by the esterases secreted by intestinal microflora (Hattori, et al.,1988; Che, et al., 1991). Once the cglycosides has been hydrolyzed, it forms the aloe-emodin, anthrone which which is further outo-oxidized to the quinine, aloeemodin. Since aloin contain a polyphenolic structure, these compounds may also responsible for the reported antiinflammatory effect of aloe (Somboonwong, et al., 2000; Korkina, et al., 2003). Accordingly, this study was performed to investigate the protective and therapeutic effect of $\mathrm{ZnONps}$ and aloin on DSS-induced ulcerative colitis in rats.

\section{Materials and method}

\subsection{Chemicals:}

Dextran sulfate sodium salt: (DSS) extracted from Leuconostoc spp. with average molecular weight of 500,000, and Aloin: from curacao aloe, molecular weight 418.29, have been obtained from (SigmaAldrich comp. for trading chemicals). $\mathrm{ZnO}$ nanogard (purity $\sim 99 \%$ ) was manufactured by Sigma Chemical Co. (St. Louis, Mo, USA) and purchased from Schnelldorf, Germany through Alfa Acer, Egypt.

\subsection{Experimental design:}

Sixty-four white albino rats of 5-7 weeks old and weighting 120-150gm were housed in separated metal cages and kept at constant environmental and nutritional conditions throughout the period of experiment. The animals were fed on constant ration and fresh, clean drinking water was supplied ad-libitum. Induction of ulcerative colitis: ulcerative colitis has been induced in rats with dextran sulfate $3 \%$ orally administrated in drinking water for 7 days (Martina Per`se and Anton Cerar 2012). Dosage of aloin and Zno nanoparticles: rats orally administerated by gavag with $1 \mathrm{ml}$ of zinc oxide nanoparticles at dose $5 \mathrm{mg} / \mathrm{kg}$ body weight (Rasmussen et al.2010), and aloin orally administered at adose $1 \mathrm{ml}$ of aloin $0.1 \%$, daily for 3 weeks (Sung et al. 2011).

\subsection{Animal groups:}


Rats were randomly divided into eight equal groups, 8 animals each, placed in individual cages and classified as following: group1(control group), feed standard pellet diet and clean drinking tab water. Group2 (UC induced group): Rats were orally received dextran sulfate $3 \%$ in drinking water. Group3 (ZnONPs administered group): rats orally administered by gavage with $1 \mathrm{ml}$ of ZnONPs $\quad(5 \mathrm{mg} / \mathrm{kg}$ body weight $)$ for 3weeks.Group4 (ZnONPs +UC group): rats with ulcerative colitis orally administered by gavage with $1 \mathrm{ml}$ of $\mathrm{ZnONPs}(5 \mathrm{mg} / \mathrm{kg}$ body weight), daily for 3 weeks. Group 5 (Aloin administered group): rats received $1 \mathrm{ml}$ aloin $0.1 \%$ orally administered by gavage for 3weeks. Group6: (aloin+ulcerative colitis groupe), rats with ulcerative colitis orally and daily administered with $1 \mathrm{ml}$ of aloin $0.1 \%$ for 3weeks. Group 7 (aloin + ZnONPs treated group): normal rats orally administered with $(1 \mathrm{ml}$ of $\mathrm{ZnONPs} \quad(5 \mathrm{mg} / \mathrm{kg}$ body weight $+1 \mathrm{ml}$ of aloin $(0.1 \%)$ daily for 3 weeks.Group 8 (ulcerative colitis + aloin + ZnONPs): rats with ulcerative colitis orally and daily administered with ZnONPs $(5 \mathrm{mg} / \mathrm{kg}$ body weight $)+1 \mathrm{ml}$ aloin $(0.1 \%)$ for 3weeks.

\subsection{Sampling:}

Blood samples and colon tissues were collected from all animal groups At the end of the experiment.

\subsubsection{Blood samples}

Blood samples were collected after over night fasting in dry, clean and screw-capped tubes. Serum was separated by centrifugation at 4000 r.p.m for $15 \mathrm{~min}$. the clear serum was received in dry, sterile sample tubes and kept in a deep feeze at $20^{\circ} \mathrm{C}$ until used for subsequent biochemical analysis. All sera analyzed for the following parameters: total cholesterol, HDL-C, TG, COX-2, TNF- $\alpha$ and IL-6.

\subsubsection{Tissue samples (colon tissue):}

At the end of the experiment, rats of each group were sacrificed by cervical decapitation. The abdomen was opened and the colon specimen was quickly removed and opened gently using a scrapper, cleaned by rinsing with ice-cold isotonic saline to remove any blood cells, clots and scraps of food, then blotted between 2 filter papers and quickly stored in a deep freezer at (-20 $\left.{ }^{\circ} \mathrm{C}\right)$ for subsequent biochemical analysis. Briefly, colon tissues were divided into appropriate portions, homogenized with a glass homogenizer in 9 volumes of ice-cold $0.05 \mathrm{mM}$ potassium phosphate buffer (pH7.4) to make $10 \%$ homogenates. The homogenates were centrifuged at 6000 r.p.m for 15 minutes at $4^{\circ} \mathrm{C}$ then the resultant supernatant were used for the determination of the following parameters: GSH, MDA

\subsection{Histopathological examination:}

Washing colon tissues was done in tap water then serial dilutions of alcohol (methyl, ethyl and absolute ethyl) were used for dehydration. Specimens were cleared in xylene and embedded in paraffin at 56 degrees in hot air oven for twenty-four hours. Paraffin bees wax tissue blocks were prepared for sectioning at 4 microns' thickness by sledge microtome. The obtained tissue sections were collected on glass slides, deparaffinized, stained by hematoxylin \&eosin stain for examination through the light electric microscope (Banchroft et al ; 1996).

\subsection{Biochemical analysis}

Serum total cholesterol, HDL-C, TG, were determined according to the methods described by (Watson, 1960), (Castelli, et al.,1977), (Trinder, et al.,1969), (Fossati, .,Principe, et al 1982), (Vassault, et al.1986) and COX- 2 ,TNF- $\alpha$ and IL- 6 estimated by ELISA kit supplied by $\mathrm{R} \& \mathrm{D}$ system Quantitative, USA. also, colon tissue Malondialdehyde (MDA) and reduced glutation (GSH) were determined according to the methods described by (Beutler et al., 1963).

\subsection{Statistical analysis}


The obtained data were statistically analyzed by one- way analysis of variance (ANOVA). All analysis performed using the statistical package for social science (SPSS, 2009). The Values were considered statistically significant when $p \leq 0.5$.

\section{RESULTS}

\section{1. effect of ZnoNps and lor aloin treatment} on some serum and colon tissue parameters of DSS-induced ulcerative colitis in rats.

The obtained results in table (1) revealed that, administration of DSS induced UC in rats exhibited a significant increase in serum total cholesterol and $\mathrm{TG}$ concentrations and significantly decreased HDL-C level when compared with normal control groups. Treatment with ZnoNps and $\backslash$ or aloin to DSS induced ulcerative colitis in rats significantly reduced elevated serum total cholesterol and TG concentrations, and increase markedly HDL-C level when compared with ulcerative colitis non-treated group. The results presented in table (2) showed that, administration of DSS induced in rats exhibited a significant increase in serum level of COX-2, IL-6, and TNF- $\alpha$ when compared with normal groups. Treatment with $\mathrm{ZnONps}$ and $\backslash$ or aloin to DSS induced ulcerative colitis in rats significantly reduced elevated level of COX-2, IL6, and TNF- $\alpha$. The 0btained results in table (3) revealed that, administration of DSS induced UC in rats exhibited a significant increase in colon tissue MDA, and significantly decreased GSH concentration when compared with normal group. . Treatment with ZnoNps andlor aloin to DSS induced ulcerative colitis in rats significantly reduced the elevated level of MDA, and markedly increase the reduced GSH level in colon tissue.

\subsection{Histological findings:}

Histopathological studies on colon tissue sections of control group showed no histological alteration were observed, while rats group which treated with DSS showed massive numbers of inflammatory cells infiltration in the colon mucosal and submucosal layers. Treatment of DSSinduced UC rats by ZnoNps and lor aloin show focal inflammatory cells in the base of the mucosa.

Table 1: Effect of ZnONps and lor aloin treatment on serum total cholesterol, Triglyceride, and HDL-C levels in DSS induced ulcerative colitis in rats and their control.

\begin{tabular}{llll}
\hline Animal groups & Cholesterol(mmol/dl) & TG $(\mathrm{mgl} / \mathrm{dl})$ & HDL $(\mathrm{mg} / \mathrm{dl})$ \\
& & & \\
\hline Control & $138.4 \pm 12.3^{\mathrm{b}}$ & $108.9 \pm 6.6^{\mathrm{b}}$ & $57.1 \pm 4.0^{\mathrm{b}}$ \\
Ulcerative colitis (uc) & $204.7 \pm 21.5^{\mathrm{a}}$ & $159.8 \pm 13.2^{\mathrm{a}}$ & $21.9 \pm 2.5^{\mathrm{a}}$ \\
$(\mathrm{NZnO})$ & $128.8 \pm 3.2^{\mathrm{b}}$ & $90.6 \pm 3.6^{\mathrm{ab}}$ & $59.3 \pm 3.9^{\mathrm{b}}$ \\
Aloin & $139.4 \pm 9.0^{\mathrm{b}}$ & $111.1 \pm 4.5^{\mathrm{b}}$ & $56.4 \pm 3.3^{\mathrm{b}}$ \\
Aloin+NZnO & $133.7 \pm 8.0^{\mathrm{b}}$ & $96.2 \pm 6.0^{\mathrm{ab}}$ & $58.7 \pm 5.8^{\mathrm{b}}$ \\
UC+NZnO & $175.2 \pm 4.4^{\mathrm{ab}}$ & $109.6 \pm 9.0^{\mathrm{b}}$ & $42.3 \pm 3.0^{\mathrm{ab}}$ \\
UC+Aloin & $131.0 \pm 11.8^{\mathrm{b}}$ & $96.9 \pm 4.1^{\mathrm{b}}$ & $59.8 \pm 6.4^{\mathrm{b}}$ \\
UC+NZnO+Aloin & $160.2 \pm 2.4^{\mathrm{ab}}$ & $82.5 \pm 1.9^{\mathrm{ab}}$ & $52.5 \pm 5.8^{\mathrm{b}}$
\end{tabular}

Data are preaented as (mean \pm SD). SD: standard deviation mean values with different superscript letters in the same column are significantly different at $(p \leq 0.5)$. 
Table 2: effect of ZnoNps andlor aloin treatment on serum COX-2 activity, IL6, and TNF- $\alpha$ levels in DSS induced ulcerative colitis in rats and their control

\begin{tabular}{llll}
\hline Animal groups & COX2 $(\mathrm{u} / \mathrm{g})$ & IL6 $(\mathrm{pg} / \mathrm{mL})$ & TNFa $(\mathrm{pg} / \mathrm{ml})$ \\
\hline Control & $1.1 \pm 0.1^{\mathrm{b}}$ & $34.7 \pm 2.4^{\mathrm{b}}$ & $33.2 \pm 4.7^{\mathrm{b}}$ \\
Ulcerative colitis (uc) & $13.1 \pm 1.7^{\mathrm{a}}$ & $149.0 \pm 12.1^{\mathrm{a}}$ & $122.9 \pm 3.9^{\mathrm{a}}$ \\
(NZnO) & $1.6 \pm 0.6^{\mathrm{b}}$ & $31.1 \pm 5.5^{\mathrm{b}}$ & $37.1 \pm 3.4^{\mathrm{b}}$ \\
Aloin & $1.2 \pm 0.08^{\mathrm{b}}$ & $30.3 \pm 5.3^{\mathrm{ab}}$ & $34.5 \pm 8.3^{\mathrm{ab}}$ \\
Aloin+NZnO & $1.0 \pm 0.01^{\mathrm{b}}$ & $31.6 \pm 3.0^{\mathrm{b}}$ & $29.9 \pm 2.2^{\mathrm{b}}$ \\
UC+NZnO & $6.1 \pm 1.9^{\mathrm{ab}}$ & $71.2 \pm 7.7^{\mathrm{ab}}$ & $68.6 \pm 12.2^{\mathrm{ab}}$ \\
UC+Aloin & $1.0 \pm 0.02^{\mathrm{b}}$ & $31.0 \pm 3.3^{\mathrm{b}}$ & $37.3 \pm 4.4^{\mathrm{b}}$ \\
UC+NZnO+Aloin & $2.2 \pm 0.4^{\mathrm{b}}$ & $51.2 \pm 9.5^{\mathrm{ab}}$ & $50.6 \pm 10.7^{\mathrm{ab}}$ \\
\hline
\end{tabular}

Table 3: effect of ZnoNps andlor aloin treatment on MDA level, and GSH level in DSS induced ulcerative colitis in rats and their control

\begin{tabular}{lll}
\hline Animal groups & MDA (mmol/mg) & GSH $(\mathrm{mmol} / \mathrm{mg})$ \\
\hline Control & $1.1 \pm 0.1^{\mathrm{b}}$ & $56.4 \pm 2.5^{\mathrm{b}}$ \\
Ulcerative colitis (uc) & $21.1 \pm 8.1^{\mathrm{a}}$ & $17.8 \pm 2.2^{\mathrm{a}}$ \\
Nano zinc oxide (NZnO) & $1.3 \pm 0.7^{\mathrm{b}}$ & $59.2 \pm 3.4^{\mathrm{b}}$ \\
Aloin & $1.2 \pm 0.05^{\mathrm{b}}$ & $59.5 \pm 3.1^{\mathrm{b}}$ \\
Aloin+NZnO & $1.1 \pm 0.07^{\mathrm{b}}$ & $61.7 \pm 3.4^{\mathrm{b}}$ \\
UC+NZnO & $6.2 \pm 0.2^{\mathrm{ab}}$ & $44.8 \pm 2.9^{\mathrm{ab}}$ \\
UC+Aloin & $0.9 \pm 0.06^{\mathrm{b}}$ & $57.1 \pm 4.3^{\mathrm{b}}$ \\
UC+NZnO+Aloin & $2.7 \pm 0.6^{\mathrm{b}}$ & $47.7 \pm 3.0^{\mathrm{ab}}$ \\
\hline
\end{tabular}

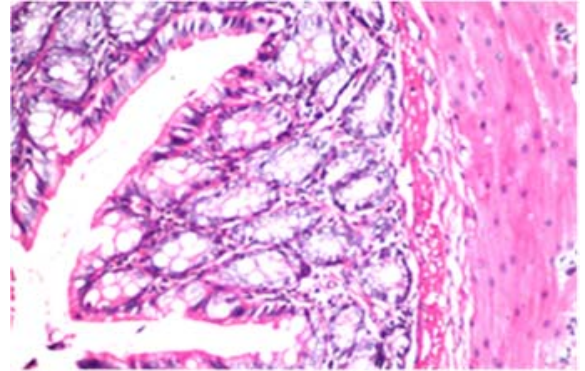

(Fig.1). Control group: There was no histopathological alteration in the colon.

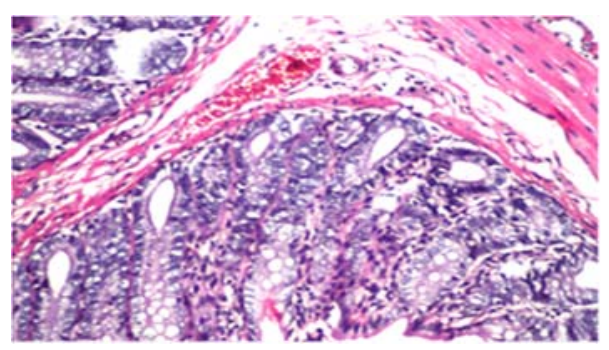

(Fig.3).Aloin and zinc oxide group: There was no histopathological alteration.

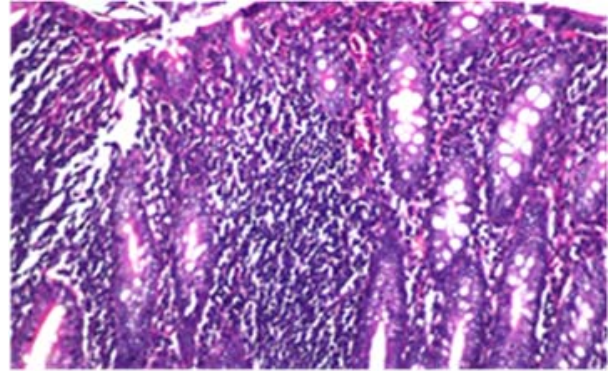

(Fig.2). UC group: The mucosal and submucosal layers showed massive numbers of inflammatory cells infiltration in the colon.

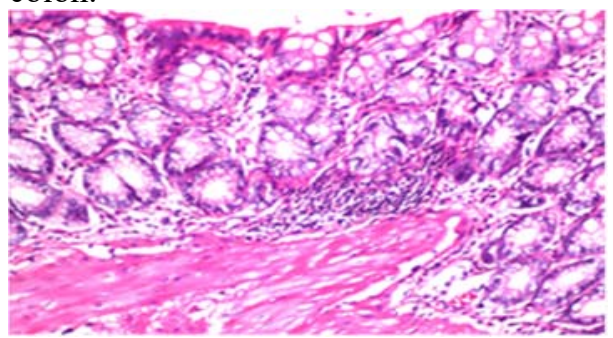

(Fig.4).UC treated with aloin and zinc oxide:

Focal inflammatory cells infiltration was noticed in the base of the mucosa. 


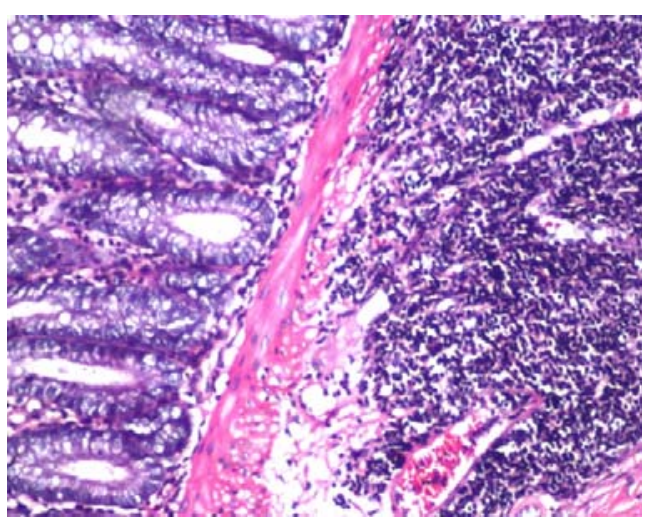

(fig.5). Group of experimentally inducted and treated by aloin: lymphoid hyperplasia was noticed in the submucosal layer.

\section{DISCUSSION}

Inflammatory bowel disease (IBD) is a complex multifactorial disease (Sartor et al., 2007,2008). It commonly refers to ulcerative colitis (UC) and Crohn's disease (CD), the two chronic conditions that involve inflammation of the intestine. Despite recent advances in treatment, there remains a need for a safe, well-tolerated therapy with a rapid onset, and increased capacity for maintaining long-term remission (Zhu et al., 2010). Aloe is widely used in the food product and pharmaceutical industries due to its biological functions of anti-inflammatory activity (Speranza et al. 2005), acceleration of wound healing (Takzare et al. 2009), and protective effect against liver injury (Arosio et al. 2000), although it is not well understood which activity is related to which component. Inflammatory bowel disease (IBD), Crohn's disease and ulcerative colitis(UC) are frequent illnesses in many parts of the world, especially in industrialized countries (Hanauer 2006). Nanotechnology represents a new and enabling platform that promises to provide a broad range of novel uses and improved

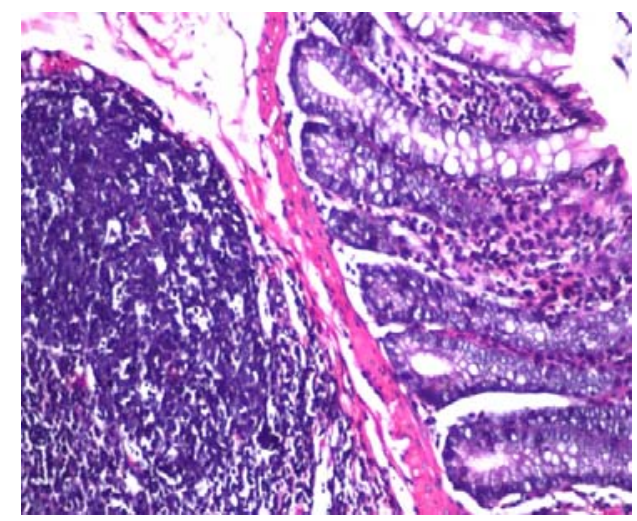

(fig.6). Group of experimentally inducted and treated by zinc oxide nano particles:

Focal inflammatory cells infiltration was observed in the lamina propria of the mucosa associated with sever lymphoid hyperplasia in the submucosal layer.

technologies for biological and biomedical applications. Treatment with ZnoNps and $\backslash$ or aloin to DSS induced ulcerative colitis in rats significantly reduced elevated serum total cholesterol and $\mathrm{TG}$ concentrations, with increase the HDL-C. This results are nearly similar to those reported by (Sung-Ho Shin et al. 2015), which said that, the treatment effectively decreased elevations in serum levels of total cholesterol and TG, and increased HDL-C level caused by DSS.

DSS as a model for studying colitisassociated carcinogenesis (De, et al., 2011) (Kanneganti, et al.,2011) who investigate the validated DSS model by using different therapeutic agents for human IBD and showed that DSS-induced colitis can be used as a relevant model for the translation of mice data to human disease (Melgar, et al., 2008). Intestinal microflora and their products have been implicated in the pathogenesis of human IBD (Sartor, 2008) (Tlaskalova-Hogenova, et al., 2004), (Prakash et al., 2011) and in several animal models (Nell ,et al.,2010). The importance of the intestinal flora is directly supported by studies of some where colitis is not observed when they are reconstituted with 
bacteria that are considered normal constituents of luminal flora It has been demonstrated that intestinal flora is implicated in the pathogenesis of DSS colitis in mice. First who suggested contribution of colonic bacteria or their products in the development of colitis in this model were Okayasu et al. (Okayasu et al.,1990). They observed increased numbers of Enterobacteriaceae, Bacteroidaceae, and Clostridium spp. in the colons of mice affected by DSS colitis (Okayasu et al., 1990).

DSS-induced breakdown of mucosal epithelial barrier function allows the entry of luminal antigens and microorganisms into the mucosa resulting in overwhelming inflammatory response Numerous inflammatory mediators have been implicated in the pathogenesis of human IBD. Changes in production of inflammatory mediators in DSS-treated mice were investigated during different phases of colitis, in the serum and/or colon and by different methods. Increased expression of different inflammatory mediators (TNF- $\alpha$ ) was observed as early as the first days of DSS treatment (Yan et al., 2009). The production of these inflammatory mediators increased progressively during DSS treatment. Different profile of inflammatory mediators in acute and chronic phase of DSS colitis was demonstrated as recorded by elevated levels of IL-6 (Alex, et al., 2009). Progressive upregulation was observed with increasing dosage of DSS (Egger et al., 2000). These inflammatory mediators not only play a role in the pathogenesis of DSSinduced colitis but are important as intervention targets against colitis as excellently described by (Kawada et al.,2007), Cytokine profile in DSS colitis correlates with clinical and histological parameters as well as barrier properties. Human and animal studies support the idea that TNF- $\alpha$ and interleukins are important pathological mediators of IBD (Malo et al. 2006; Brynskov et al. 1992). In humans with IBD, approximately two-thirds of patients respond to anti-TNF- $\alpha$ treatments (Papadakis and Targan 2000), and intestinal inflammation is attenuated significantly by anti-interleukiens and/or anti-TNF- $\alpha$ monoclonal antibodies in mice (Ogata and Hibi 2003; Atreya et al. 2000). TNF- $\alpha$ and interleukiens as IL-6 mRNA expressions in the colon of DSS-exposed rats are dramatically increased compared to noncolitic rats, suggesting that immune cells are attracted to the site of inflammation. Dietary aloin, supplementation significantly decreased these inflammatory cytokine expressions in a dose-dependent manner. In this study, aloe components clearly suppressed the expression of TNF- $\alpha$ and IL-6 in the colon (Park et al.,2011)

This results are similar also to those which reported by (Sung-Ho Shin et al. 2015).

COX-2 can be activated to produce excessive PGE2, an important inflammatory mediator in IBD (El-Medany et al.,2005). COX-2 is proinflammatory protein that play a pivotal role in mediating inflammation and contribute to chemicalinduced inflammation in mice (Hsiang CY,et al.,2013). In the present study aloin and \ or ZnoNps was found to be significantly down regulate $\mathrm{COX}-2$ expression in colon.

COX-2 enzyms ,which catalyze prostaglandin biosynthesis, has become an important target for the discovery and development of new anti-inflammatory agents (Park et al.,2009) . Aloin structureactivity study has indicated that more than 2 hydroxyl groups on the B ring were important for suppression of COX-2 transcription activity (Mutoh et al., 2000). The current study showed that, the value of MDA level, a marker of oxidative stress, was significantly higher in the DSS group. Mean while in treatment groups the MDA levels in the colonic tissue markedly decreased compared with the DSS groups. This similarly, agreement (Hussein et al. 2014) which proved that serum MDA level was significantly decreased in diabetic rats treated with ZnONPs. Zinc is a necessary factor in the variety of antioxidant enzymes 
e.g. Zn super oxide dismutase, Znmetallothionein etc, (Arthur,1998). Other investigators have suggested that, the $\mathrm{Zn}$ metallothionein complex in the islets cells provides protection against free radicals produced in the cell from any cause. The more depleted the intracellular $\mathrm{Zn}$ stores, the less able the cell is to defend itself against this oxidative load, It has been proposed that an imbalance between prooxidant and antioxidant mechanisms may play an important role in the development of intestinal inflammation and mucosal tissue injury in colitis (Sengul et al. 2010). GSH plays a common role in cellular resistance to oxidative damage as a free radical scavenger as protein-bound GSH and by generation of ascorbate and/or tocopherol in liver (Mark et al., 1996). Treatment cause a significant increase in GSH level. This results were nearly similar to those reported by Manikandan et al., (2011) who showed that, curcumin reversed the effect of gentamycin, by significantly increasing GSH activity in the kidney tissue.

\section{CONCLUSION}

Administration of $\mathrm{ZnONPs}$ and $\backslash$ or aloin to rats with ulcerative colitis significantly reduced elevated serum total cholesterol and TG concentrations, and markedly increased the reduced HDL-C level. On the other hand, elevated level of COX-2, IL-6, MDA and TNF- $\alpha$ in UC rats were significantly reduced, with significant increase of the reduced level of GSH. Results suggest that ZnONPs modulates UC, while aloin showed high efficacy to normalize UC tissues and may considered as potential treatment for UC and other inflammatory bowel disease.

\section{REFERENCES}

Alex, P., Zachos,N.C., Nguyen, T. etal., 2009. "Distinct cytokine patterns identified from multiplex profiles of murine DSS and TNBS-induced colitis," Inflammatory Bowel Diseases.
Ando, N., Yamaguchi, I., 1990. Sitosterol from Aloe vera (Aloe 6era(L.) Burm. f.) gel. Kenkyu Kiyo-Tokyo Kasei Daigaku 30.

Arosio, B., Gagliano, N, Fusaro, L.M., Parmeggiani, L., Tagliabue, J., Galetti, P, et al. 2000. Aloe-emodin quinone pretreatment reduces acute liver injury induced by carbon tetrachloride. Pharmacol Toxicol.

Arthur, B.C. 1998. Zinc, Insulin and Diabetes. J Am Coll Nutri.

Atreya R, Mudter J, Finotto S, Müllberg J, Jostock T, Wirtz S, et al. 2000.

Blockade of interleukin 6 trans signaling suppresses T-cell resistance against apoptosis in chronic intestinal inflammation: evidence in Crohn's disease and experimental colitis in vivo. Nat Med.

Egger B., M. Bajaj-Elliott, T.T. MacDonald, R. Inglin, V.E. Eysselein, and uchler M.W. B" 2000. "Characterization of acute murine dextran sodium sulphate colitis: cytokine profile and dose dependency," Digestion, vol. 62.

Banchroft, J.D.; Stevens, A. and Turner, D.R. (1996) Brynskov J, Tvede N, Andersen $\mathrm{CB}$, Vilien M. Increased concentrations of interleukin 1 beta, interleukin-2, and soluble interleukin-2 receptors in endoscopical mucosal biopsy specimens with active inflammatory bowel disease.

Castelli, W.P., et al., 1977. Chabni M., Bougherra H., Lounici H., Ahmed-Zaïd T, Canselier J-P, Bertrand J. Evaluation of the Physical Stability of Zinc Oxide Suspensions Containing Sodium Poly(acrylate) and Sodium Dodecylsulfate. J. Dispersion Sci. Technol (2011).

Chabni M., Bougherra H., Lounici H., AhmedZaïd T, Canselier J-P, Bertrand J. (2011)Evaluation of the Physical Stability of Zinc Oxide Suspensions Containing Sodium Poly-(acrylate) and Sodium Dodecylsulfate. J. Dispersion Sci. Technol.

Choi, S., Chung, M.H., 2003. A review on the relationship between Aloe vera compo-nents and their biologic effects. Semin. Int. Med.

Davis, R.H., DiDonato, J.J., Johnson, R.W., Stewart, C.B.,(1994). Aloe vera, hydrocortisone, and sterol influence on wound tensile strength and antiinflammation. Journal of the 
American Podiatric Medical Association 84.

De,R.M., E.Massi,M.L.Poeta,etal., 2011 "The AOM/DSS murine model for the study of colon carcinogenesis: from pathways to diagnosis and therapy studies," Journal of Carcinogenesis, vol. 10, article 9.

Dignass,A.,et.al. Second European evidencebased consensus on the diagnosis and management of ulcerative colitis part 1: Definitions and diagnosis. Journal of Crohn's and Colitis. 2012;6:965

El-

Medany,A.,Mahgoub,A.,Mustafa,A.,Ara fa,M.,Morsi,M. 2005The effects of selective cyclooxygenase-2 inhibitors, celecoxib and rofecoxib, on experimental colitis induced by acetic acid in rats. Eur J Pharmacol.

Fossati,P.,Principe, et al.Clin.Chem.28. 1982.

Hogenova-

Tlaskalova,H.,Stepankova,R.T.Hudcovi

c,et,al., "Commensal

bacteria (normal microflora), mucosal immunity and chronic inflammatory and autoimmune diseases,"Immunology Letters 2004.

Hanauer,SB. Inflammatory bowel disease: epidemiology, pathogenesis, and therapeutic opportunities. Inflamm Bowel Dis 2006.

Hsiang,CY.,Lo

HY, Huang,HC.,LiCC,WuSL,Ho,TY2013.Gi nger extract and zingerone ameliorated trinitrobenzene sulphonic acid-induced colitis in mice via modulation of nuclear factor- $\kappa \mathrm{B}$ activity and interleukin-1 $\beta$ signalling pathway. Food Chem.

Hattori,M.,Kanda,T.,ShuYZ,Akao,T.,Kobashi, K.,and Namba,T., Chem .pharm , Bull.( Tokyo), 1988.

John,W. Rasmussen1, Ezequiel Martinez1, Panagiota Louka1, and Denise, G. Expert Opin Drug Deliv. 2010 September. Zinc Oxide Nanoparticles for Selective Destruction of Tumor Cells and Potential for Drug Delivery Applications

Kanneganti,M., Mino-Kenudson,M. and Mizoguchi, E., 2011 "Animal models of colitis-associated carcinogenesis,"
Journal of Biomedicine an Biotechnology, Article ID 342637.

Kawada,M., Arihiro,A. and Mizoguchi,E. 2007 "Insights from advances in research of chemically induced experimental models of human inflammatory bowel disease," World Journal of Gastroenterology, vol. 13 , no. 42.

Kitajima,S.,Takuma,S. and Morimoto,M. 1999

"Tissue distribution of dextran sulfate sodium (DSS) in the acute phase of murine DSS-induced colitis," Journal of Veterinary Medical Science, vol. 61, no. 1.

Kitajima,S., Morimoto,M. and Sagara,E. 2002 "A model for dextran sodium sulfate (DSS)-induced mouse colitis: bacterial degradation of DSS does not occur after incubation with mouse cecal contents," Experimental Animals, vol. 51, no. 2,.

Koichi,Achiwa. 2015. Biochemical and Biophysical Research Communications xxx.

Korkina, L., Suprun, M, Petrova, A, Mikhal'chik, E., Luci, A. and Deluca, C 2003, Biofactors, 18.

Malo, MS., Biswas, S., Abedrapo, MA., Yeh, L., Chen, A., Hodin, RA. 2006The proinflammatory cytokines, IL-1beta and TNF-alpha, inhibit intestinal alkaline phosphatase gene expression. DNA Cell Biol,.

Manikandan, R.; Beulaja, M.Thiagarajan, R. Priyadarsini, A. Saravanan, R. and Arumugam, M.2011: Ameliorative effects of curcumin against renal injuries mediated by inducible nitric oxide synthase and nuclear factor kappa B during gentamicin induced toxicity in Wistar rats. European Journal of Pharmacology.

Mark, D.Ip,S., Li, P. Poon, M. and KO,K. 1996: Alterations in tissue glutathione antioxidant system in streptozotocininduced diabetic rats. Mol. Biochem, 20(162).

Martina. Per`se, and Cerar, A. 2012. This is an open access article distributed under the Creative Commons Attribution License, which permits unrestricted use,distribution, and reproduction in any medium, provided the original work is properly cited. 
Melgar, S., Karlsson, A., and Michaelsson, E., 2005 "Acute colitis induced by dextran sulfate sodium progresses to chronicity in $\mathrm{C} 57 \mathrm{BL} / 6$ but not in $\mathrm{BALB} / \mathrm{c}$ mice: correlation between symptoms and inflammation," American Journal of Physiology, 288(6).

Melgar, S., Engstrom, K., Jagervall A., and Martinez V., 2008 "Psychological

stress reactivates dextran sulfate sodiuminduced chronic colitis in mice," Stress, vol. 11, no. 5.

Melgar, S., Karlsson, L., Rehnstrom, E. et al.,2008 "Validation of murine dextran sulfate sodium-induced colitis using four therapeutic agents for human inflammatory bowel disease," International Immuno pharmacology, vol. 8 , no. 6.

Mi-Young Park a, Hoon-Jeong Kwon b, MiKyung Sung Life Sciences 88. 2011 Contents lists available at ScienceDirect

Mutoh, M, Takahashi, M., Fukuda, K., Matsushima-Hibiya, Y, Mutoh, H., Sugimura T, and Wakabayashi K, Carcinogenesis, 2000.

Neurath, M., Fuss, I., and Strober, W., 2000 "TNBS-colitis," International Reviews of Immunology, vol. 19, no. 1.

Nell S., Suerbaum S, and Josenhans C., 2010. The impact of the microbiota on the pathogenesis of IBD: lessons from mouse infection models," Nature Reviews Microbiology, vol. 8, no. 8 .

Ogata H, Hibi T. 2003Cytokine and anticytokine therapies for inflammatory bowel disease. Curr Pharm Des.

Okayasu, I., S. Hatakeyama, M. Yamada, T. Ohkusa, Y. Inagaki, and Nakaya, R. 1990 "A novel method in the induction of reliable experimental acute and chroniculcerative colitis in mice," Gastroenterology, vol. 98, no. 3.

Park M-Y, Hoon-Jeong Kwon , and Mi-Kyung Sung. 2009. Anti-inflammatory effect of aloe ingredient. Biosci. Biotechnol. Biochem.,73(4).

Papadakis, KA., Targan, SR. 2000 Role of cytokines in the pathogenesis of inflammatory bowel disease. Annu Rev Med.

Pilar .M. ;Mitjans, M . 2015Antitumor activities of metal oxide nanoparticles . Nanomaterials .
Prakash, S., Tomaro-Duchesne, u.C., Saha, S., and Cantor, A., 2011 "The gut microbiota and human health with an emphasis on the use of microencapsulated bacterial cells," Journal of Biomedicine and Biotechnology, vol. 2011, Article ID 981214.

Rakel, D. Integrative Medicine. 3rd ed. Philadelphia, Pa.: $\quad$ Saunders Elsevier; 2012. $\quad$ http://www. clinicalkey.com. Accessed June 4, (2014).

Ramimoghadam, D., Hussein, MZB., TaufiqYap, YH. 2012 The Effect of Sodium Dodecyl Sulfate (SDS) and Cetyltrimethyl ammonium Bromide (CTAB) on the Properties of $\mathrm{ZnO} \quad$ Synthesized by Hydrothermal Method. Int. J. Mol. Sci.;13.

Ray, A., DuttaGupta, S., Ghosh, S., 2012.I solation and characterization of potent bioactive fraction with antioxidant and UV absorbing activity from Aloe barbadensis Miller gel. J. Plant Biochem. Biotechnol.,http://dx.doi.org/10.1007/s1 3562-012-0178-2

Ray, A., Dutta Gupta, S., Ghosh, S., 2013. Evaluation of anti-oxidative activity and UV absorption potential of the extracts of Aloe vera L. gel from different growth periods of plants. Ind. Crop. Prod. 49.

Rodriguez-Gonzalez, V.M., Femenia, A., Gonzalez-Laredo, R.F., RochaGuzman, N.E., Gallegos-Infante, J.A., Candelas-Cadillo, M.G., Ramírez-Baca, P., Simal, S., Rossello, C., 2011. Effectsof pasteurization on bioactive polysaccharide aceman-nan and cell- wall polymers from Aloe barbadensis Miller. Carbohydr. Polym. 86(4).

Samy Ali Hussein1, Yakout A. EL-Senosi1, Khalifa El-Dawy2, Hind A. Baz. 2014Protective effect of Zinc Oxide nanoparticles on oxidative stress in diabetes in rats. Benha veterinary medical journal, 27.

Sartor, R.B. and Muehlbauer, M. 2007 "Microbial host interactions in IBD: implications for pathogenesis and therapy," Current Gastroenterology Reports, 9. 
Sartor, R.B., 2008 "Microbial influences in inflammatory bowel diseases," Gastroenterology, vol. 134.

Sengul, N, Isik, S., Aslim, B., Ucar, G., Demirbag, AE. 2010 The effect of exopolysaccharide producing probiotic strains on gut oxidative damage in experimental colitis. Dig Dis Sci;56.

Somboonwong, J, Thanamittramanee, S., Jariyapongskul, A., and Patumraj, S.J. Med. Assoc. Thai., 83, 2000.

Speranza, G, Morelli, CF, Tubaro, A., Altinier, G, Durì, L, Manitto,P. Aloeresin I, 2005 an anti-inflammatory 5methylchromone from cape aloe. Planta Med.

Sung-Ho, Shin, Jia-Le, Song1, Myoung-Gyu Park, Mi-Hyun Park, Sung-Joo Hwang and Kun-Young Park12015§ Nutrition Research and Practice; 9(6).

Takzare, N, Hosseini, MJ, Hasanzadeh, G, Mortazavi, H, Takzare A, Habibi P. 2009. Influence of Aloe Vera gel on dermal wound healing process in rat. Toxicol Mech Methods 19(1).

Trinder, P., Ann Clin Biochem. 6 (24):1969. Umrani, R.D., Paknikar, K.M. 2014. Zincoxide nanoparticles show antidiabetic activity in streptozotocininduced Types 1 and 2 diabetic rats. Nanomedicine. 9.

Umrani, R.D., Paknikar, K.M. 2014. Zinc
Oxide nanoparticles show antidiabetic activity in streptozotocin induced Types1 and 2 diabetic rats. Nanomedicine. 9:

Vassault, A. et al. Ann.Biol. Clin., 44: $686,1986$.

Wahab, R.; Dwivedi, S.; Umar, A.; Singh, S.; Hwang, I.H.; Shin, H.S.; $\quad$ Musarrat, J.; Al-Khedhairy,A.A.; Kim, Y.S. 2013 $\mathrm{ZnO}$ nanoparticles induce oxidative stress in Cloudman S91melanoma cancer cells. J. Biomed. Nanotechnol.

Waller, G.R., Mangiafico, S., Ritchey, C.R., 1978. A. Chemical investigation of Aloe barbadensis Miller. Proceedings of the Oklahoma Academy of Science.

Wirtz,S., and Neurath,M.F., 2007 "Mouse models of inflammatory bowel disease," Advanced Drug Delivery Reviews, vol. 59, no.11.

Wirtz, S., Neufert, C., Weigmann, B., and Neurath, M.F., 2007 "Chemically induced mouse models of intestinal inflammation," Nature Protocols, 2(3).

Yan, Y., Kolachala, V., Dalmasso G. et al., 2009 "Temporal and spatial analysis of clinical and molecular parameters in dextran sodium sulfate induced colitis," PLoS One, 4:6, ID e6073.

Zhu, L.J., Yang, X., and Yu,X. Q., 2010 “AntiTNF-alpha therapies in systemic lupus erythematosus," Journal of Biomedicine and Biotechnology, vol. 2010, Article ID 465898. 